\title{
O GOLPE DE 1964 NO BRASIL: MEMÓRIAS DE MULHERES SOBRE O EXÍLIO
}

\author{
Débora Mazzal \\ Márcia dos S. Ferreora ${ }^{2}$ \\ Nima I.Spigolon ${ }^{3}$
}

\begin{abstract}
Resumo: O artigo analisa o exílio a partir de memorias de mulheres brasileiras da geração de 1968 que saíram do pais entre 1970/71. Sugere pensá-lo a partir de duas perspectivas: a do autoritarismo de Estado e da memória de exiladas. Disserta sobre as experiências delas; as estratégias mobilizadas; as rotas perseguidas; a inserção em outro estado nacional; as visões de mundo e de Brasil; e a condição de mulher. A metodologia traz a escrita de uma história coletiva, despersonalizada, caracterizando pontos de convergência e divergência entre os percursos. As memórias apontam que o exílio vivido por essas mulheres foi marcado pelas relações de sexo/gênero, reconversões identitárias e por definições políticas.
\end{abstract}

Palavras-chave: Exílio. Mulheres. Memórias.

Abstract: The article analyzes the exile from memories of the 1968 generation Brazilian women who left the country between 1970/71. Suggests thinking it from two perspectives: that of the State authoritarianism and exiled memory. Talks about their experiences; the strategies mobilized; the persecuted; the insertion in another State; the worldviews and Brazil; and the condition of woman. The methodology brings the writing of a collective story, de-personalized, featuring points of convergence and divergence between the paths. The memories indicate that exile experienced by these women was marked by sex/gender relations, identity and political definitions reconversions.

Keywords: Exile. Women. Memories.

O golpe de 1964 no Brasil completou meio século, um tempo que permanece vivo.

Pós-doutorado em Sociologia pelo Laboratoire Genre, Travail et Mobilité/Paris e pelo Centre de Recherche sur le Brésil Contemporain/Ecole des Hautes Etudes en Sciences Sociales/Paris. Doutorado e Mestrado em Ciências Sociais pela UNICAMP, graduação em Pedagogia. Professora da Faculdade de Educação da UNICAMP, credenciada no Programa de Pós-Graduação em Educação. E-mail: dmazza@unicamp.br

2 Pós-doutorado em Educação pela UNICAMP. Doutorado e Mestrado em Educação pela USP, graduação em Ciências Sociais pela UNICAMP, graduação em Ciências Econômicas. Professora do Instituto de Educação da UFMT, credenciada no Programa de Pós-Graduação em Educação. E-mail: msf@uftm.br

3 Doutorado em Ciências Sociais na Educação e Mestrado em Educação pela UNICAMP, graduação em Pedagogia e Administração. Professora da PUC-Campinas. Integrante do GEPEJA e GPPE, ambos da FE/UNICAMP. Email:professoranima@gmail.com 
Sem condições de aprofundar é importante analisar o golpe de 1964 como parte do processo histórico marcado por transformações econômicas, políticas e sociais à época em curso na sociedade brasileira (BAUER, 2012; FERNANDES, 1975; REZENDE, 2001; DREIFUSS, 2008; GORENDER, 1987; TOLEDO, 1982).

Os acontecimentos advindos desse processo marcaram a história do país e a vida dos brasileiros e brasileiras. Dentre eles há a ditadura e o exílio, que englobam condições sociais coletivas coadunadas às situações particulares dos indivíduos.

O exílio nos compele a refletir sobre a existência humana com base em experiências "de fraturas entre o ser humano e um lugar natal, o eu e seu lar [...] é um esforço para superar a dor mutiladora da separação [...] a perda de algo deixado para trás" (SAID, 2003, p.46). O exílio pode ser compreendido como um mecanismo de eliminação e afastamento de grupos questionadores e opositores da ordem estabelecida a partir do golpe de 1964 e como uma experiência vivida por duas gerações, a de 1964 e a de 1968, ambas expulsas pela ditadura. Embora as saídas do pais tenham ocorrido antes, durante e após essas datas percebe-se diferentes ciclos de violência e repressão que permitem caracterizar duas gerações de exilados $^{4}$ (ROLLEMBERG, 1999).

O foco do artigo é o exílio com base em de memórias ${ }^{5}$ de mulheres brasileiras, da geração de 1968, que saíram em 1970 e 1971, cuja narrativa ${ }^{6}$ dos fatos passados ajuda a alinhavar a vida política do país.

Elas são identificadas e se identificam como sujeitos políticos que participaram de ações públicas, por isso classificadas no contexto político, econômico e social da época como criminosas, foragidas, perigosas, anticívicas (CAVALCANTI; RAMOS, 1978) e tratadas de modo pejorativo em decorrência das relações de sexo/gênero ${ }^{7}$ estabelecidas.

$\mathrm{O}$ exílio acomete maciços populacionais deslocados de forma crescente a partir do século XX, sendo o exílio político tomado como escola de

\footnotetext{
Rollemberg (1999) entende que a geração de 1964 é marcada por cassações vinculadas ao governo Jango e a geração de 1968 é atingida pelo AI-5 que acossa as organizações clandestinas, os movimentos estudantis e a luta armada.

5 Larrosa (2002) diz que memória não é a recoleção objetiva dos fatos passados, mas interpretação e construção, imaginação e composição, ancorada nas coordenadas espaço-tempo e nas mediações da linguagem. É o tempo narrado na história com base em experiências que nos passam, acontecem e tocam.

6 Benjamin (1997) entende a narrativa como a capacidade de trocar experiências através do contato humano que é o disparador da arte de narrar. Podemos contar e recontar histórias recorrendo ao acervo das experiências vividas ou relatadas por outros. Na narrativa a história é objeto de construção e os tempos e lugares estão em rearranjos constantes embaralhando o factual e o sensível.

Para Dussuet, Flahault, Loiseau (2013) a categoria de gênero não é sinônima de sexo. Ela designa um sistema social que cria e legitima a bi-categorização sexual, um conjunto de normas sexuadas e a perpetuação de relações de dominação entre os sexos.
} 
militância repleta de paradoxos (DUSSUET; FLAHAULT; LOISEAU 2013). Nesse sentido o exílio impacta e produz sentimentos de provisoriedade, uma vez que as mulheres aqui viveram experiências, processos de reconversão ${ }^{8}$ identitária e construção dos vínculos familiares, profisssionais, sociais, considerando que as rupturas implicavam adaptações - melhor ou pior sucedidas - a outros lugares e ao estabelecimento de outras relações. Tal associação suscita perguntas que orientam nossas análises: Como se deu a punição política do exílio? Quais estratégias para sair? Quais rotas perseguidas? Como foi a inserção em outro Estado nacional? Como o exílio afeta a visão de mundo e de Brasil? A condição de mulher é impactada pelo exílio?

A experiência dos deslocamentos provocados pelo exílio compõe um repertório de valor significativo que merece ênfase na reflexão sociológica sobre as formas de vida, os projetos de sociedade, as transformações identitárias e os sentidos conferidos pelas mulheres às suas ações privadas e públicas.

\section{(INTER) REFERÊNCIAS}

É possível pensar o exílio com base em uma chave dupla, a do autoritarismo de Estado, que é política e coletiva, e a da narrativa, neste caso, as mulheres e suas memórias (YANKELEVICH; JENSEN, 2007).

O exílio marca a humanidade e discuti-lo é uma forma de recusar situações sociais de exclusão, discriminação e violação de direitos. É insuficiente fazê-lo apenas sob as óticas política e jurídica, é preciso descobrir estratégias, mapear percursos e reconhecer que o individual e o social se complementam numa perspectiva histórica.

Os depoimentos ${ }^{9}$ focalizados identificam relações que permanecem embaçadas, como as de gênero que estruturam, mantêm e reproduzem desigualdades nas práticas sociais pautadas no marcador do sexo.

Não as caracterizamos como vítimas, pois isso coadunaria com a lógica dos agentes da repressão no final dos anos 1960, quando, após agredi-las, referiam-se a elas como "pobres moças". Intentamos dar visibilidade ao exílio brasileiro e às violências acometidas contra mulheres num sistema em que as relações de dominação dos homens perduram inclusive nas organizações políticas. Elas se apresentam como sujeitos sexuados que participaram da luta política no Brasil e depois no mundo.

\footnotetext{
O conceito de reconversão potencializa processos de formação/construção de identidades ou de composição/ recomposição dos percursos de sujeitos ou grupos. "[...] dão visibilidade a processos de rupturas de itinerários e colocam em foco as desvalorizações e/ou reavaliações dos recursos econômicos, culturais, sociais e simbólicos detidos [...] dão lugar a deslocamentos no espaço social, através do abandono de posições instituídas" (SAINT MARTIN, 1995, p. 1023).

9 Queiróz (2008) sugere que os depoimentos são narrativas temáticas conduzidas pelo pesquisador.
} 
Optamos por um conceito amplo de exílio. São exiladas as vítimas de punição, prisão, tortura, as que sofreram perseguições indiretas, estudantes, esposas, mães, filhas e militantes, as que perderam suas condições de trabalho, as que não suportaram as formas de opressão da ditadura. E ainda as que insistiram em ser livres quando as liberdades estavam cerceadas (COSTA [et. al.], 1980).

Com o golpe de 1964 e a ditadura, a saída do país é, na maioria das vezes, limitada ao absurdo de ficar e morrer ou sair e viver. O exílio é uma resultante dessa situação política limítrofe que gerou diversos graus de recusa/aceitação, várias formas de viver em certas condições, diferentes modos de como as identidades de mulheres e homens foram afetadas.

Há exílios no que concernem a duração, inserções, percepções e definições. Então, o exílio pode ser dentro do Brasil: clandestinidade, marginalização geográfica/cultural, perda de vínculos, ruptura com a militância; e fora: a legalização, o assumir-se exilada, manter-se brasileira, o medo de voltar e sentir-se estrangeira. Múltiplas são as experiências, as reconversões identitárias e as formas de encará-las.

Operamos com a ideia de que as identidades individuais e coletivas estão em movimento de desestruturação/reestruturação, cuja dinâmica assume a aparência de uma crise de identidades. Assim, as identidades não são nem expressões psicológicas de personalidades individuais nem produtos de estruturas sociais ou de políticas impostas de cima, mas construções sucessivas de apropriações ocorridas em processos diversificados de ações recíprocas entre os sujeitos e os diversos âmbitos de integrações sociais. Elas resultam de negociações, precárias e fecundas, de processos de apropriações e constituem expressões sociais em construção (DUBAR, 2005; DUBET, 1996; HELLER, 1977) ${ }^{10}$.

Utilizamos o conceito de circulação porque ele recobre situações em que a mobilidade predomina como elemento organizador das dinâmicas sociais, individuais e grupais (CORTES; FARET, 2009). Consideramos que a circulação experienciada por essas mulheres é qualificada como diaspórica, à medida que impulsiona construções identitárias decorrentes de diferentes tipos de relações com os países de origem, acolhida, condições de inserção e redes relacionais. Nesse sentido, a memória individual e coletiva se liga à multiplicidade de tempos e lugares vividos na diáspora (BRUNEAU, 2009; HALL, 2006).

\footnotetext{
Nesta perspectiva a identidade é apreendida como trabalho que envolve condutas, papéis, posições sociais, cultura, orientações ancoradas pelos sujeitos a partir das experiências. Identidade é resultante das operações de diferenciação (singularidade) e generalização (pertencimento comum).
} 
O material apresentado não tem peso estatístico e não permite generalizações do tipo quantitativo. São narrativas que misturam fatos vividos e percepções pessoais. Portanto, não consideramos as reflexões desenvolvidas uma amostragem representativa do exílio brasileiro, mas uma expressão factual e sensível de exiladas (BAUER, GASKELL 2010). Trabalhamos com o depoimento de quatro mulheres brasileiras exiladas em decorrência da exceção aberta pelo Ato Institucional (AI) 5, de 1968, a Emenda Constitucional (EC) 1, do AI 13 e do Decreto-Lei (DL) 477, ambos de 1969, entre outros dispositivos legais (CAVALCANTI \& RAMOS, 1978; HIRATA, 2011).

Três depoimentos são fontes secundárias já publicadas (CARVALHO; LISBOA; ROCHA, 1978) e um depoimento é fonte primária inédita coligida pelas autoras (HIRATA, 2011). As memórias das mulheres sobre a experiência do exílio vivida após 1968 alinham o artigo, mesmo considerando a decalagem temporal da construção das narrativas.

Metodologicamente aportamos na escrita de uma história coletiva, despersonalizada, que apresenta elementos dos depoimentos selecionados e cujo sentido é identificar pontos de convergência e divergência entre as memorias das mulheres sobre os percursos, as relações de gênero e as transformações identitárias no exílio.

Isso sugere que "as ações sofridas no tempo são despersonalizadas na medida em que se referem a funções sociais, a entes gerais, e não a pessoas ou atos indicados a dedo e reconheciveis". É possível "abstrair a pessoa $A, B$ ou $C$, para falarmos de modo genérico, de sujeitos que desempenham funções e, preservam o conteúdo social que as relações entre os indivíduos implicam." (FERNANDES, 2004, p.247).

MEMÓRIAS DE EXILADAS

As mulheres que tomamos como fonte de compreensão do exílio tiveram estudos em nível superior e ligação direta com o movimento estudantil atuando como estudantes engajadas, profissionais que defendiam o direito de estudantes presos ou militante de grupo de esquerda. Viveram a repressão ditatorial no Brasil, enfrentaram processos criminais ao mesmo tempo em que se intensificava o aparato violento do governo nos quadros de: delação, inquérito, prisão, clandestinidade, acusações e tortura. Mencionam situações relativas à condição da mulher, tais como a maternidade.

Punição POLítica do EXÍlio

Essas mulheres saíram do Brasil na vigência do AI 5, AI 13, e da EC 1. Esse conjunto de documentos autorizava: "suprimir a garantia de habeas 
corpus, nos casos de crimes políticos, contra a segurança nacional, a ordem econômica e social" (AI 5, Art. 10), atribuir ao presidente da República o poder de "suspender os direitos políticos de quaisquer cidadãos pelo prazo de 10 anos e cassar mandatos eletivos federais, estaduais e municipais" (AI 5, Art. 4), e "banir do Território Nacional o brasileiro que, comprovadamente, se tornar inconveniente, nocivo ou perigoso à Segurança Nacional" (AI 13, Art. 1). As penas de morte, prisão perpétua e banimento foram acrescentadas à Constituição de 1967 pela EC 1, de 1969, e somente suprimidas em 1978. Nas instituições de ensino, de todos os níveis, o DL 477, de 1969, foi utilizado para proibir manifestações políticas, sobretudo no ensino superior, vistas como subversivas ou contrárias à moral e à ordem pública.

O contexto jurídico em vigor colocava em risco a segurança de qualquer pessoa acusada de envolvimento em movimentos políticos de esquerda e se tornou fator decisivo para seu exílio.

Em ordem cronológica, os depoimentos trazem a situação vivida e o acirramento da repressão por parte do governo.

Há referências a prisões no $30^{\circ}$ Congresso da União Nacional dos Estudantes (UNE), em 1968, quando a tortura não se fez presente: " $O$ golpe foi 1964, teve AI 5, em 1968, tinha sido presa [...] ficado 10 dias em Ibiúna [...] com mais de mil pessoas [...] acho que foi 3 dias [...] no Carandiru uma semana, depois fomos soltos, naquela época não tinha repressão com tortura (HIRATA, 2011)."

Há as que se reportam a 1969 com violência e repressão explícitas:

\footnotetext{
Em abril de 1969, vários de nós fomos enquadradas no DL 477 e, a partir daí, eu não podia entrar na escola, nem os alunos podiam falar com os enquadrados. Sentia-se o medo crescente. Uma vez, um companheiro tentou fazer manifestação na escola. Em cinco minutos, o diretor chamou a repressão, ele foi preso e apanhou muito (ROCHA, 1978, p.178).

Depois do AI 5 a nossa luta foi contra o DL 477, que proíbe a atividade nas escolas e expulsa estudantes e professores que o fizerem [...] Começa repressão violenta, o diretor toda hora chamando a polícia [...] A gente na sala de aula e entravam os policiais, revólver para cima, mandando encostar na parede (LISBOA, 1978, p. 241).
}

As atividades profissionais da advogada que acompanhava a detenção de envolvidos com movimentos estudantis e políticos retratam que:

Até 68, cada vez que havia manifestações, passeatas, ou qualquer outra coisa, causando prisões, eu intervinha. Defendi centenas de pessoas [...] Nos congressos da UNE [...] sempre intervinha ajudando a soltar o pessoal. Cheguei a ter, numa leva, 300 que foram soltos de uma vez só. Nesse primeiro período de 
advocacia política ainda existia o habeas-corpus e garantias individuais. Depois [...] veio o AI-5 e com ele a triste realidade da tortura, com todas dificuldades que surgiram para o exercício da profissão. (CARVALHO, 1978, p.58).

\section{Essa intensificação da realidade foi determinante para o exílio:}

Em 1969 fui interrogada mais uma vez [...] era diferente, ameaça de tortura. Uma pessoa deu meu nome não como advogada mas como militante. Tive que assinar uma declaração de que só trabalhava como advogada, que não defendia ninguém de graça [...] só trabalharia mediante contrato e honorários. A partir de 70 as coisas foram piorando. Sofri perseguição, ameaças na própria Auditoria, na Operação Bandeirantes. Houve censura em minha correspondência [...] De 68 a 71 sofri de pesadelo profissional [...] Eu ia à cadeia todos os dias, das 9 às $12 \mathrm{~h}[\ldots]$ A cadeia, $\mathrm{o}$ contato permanente com os presos foi uma grande escola para mim. Nos primeiros dias de 71 as coisas pioraram e saí do Brasil (CARVALHO, 1987, p.58-61).

Em Abril de 1969 a polícia começou a me procurar em casa [...] eu não podia mais viver com a família [...] Uma noite, a casa onde eu vivia com meu companheiro foi atacada a bala [...] Eram 16 policiais armados e acabaram com a casa [...] O que nos salvou foi não estarmos lá [...] Fui para Fortaleza [...] Fiquei trabalhando pela organização e participando do trabalho no campo [...] daí veio uma busca intensa no Ceará. Fui para o Rio Grande do Norte [...] o cerco policial apertava [...] $\mathrm{Na}$ realidade as organizações não dispunham de uma estrutura para deslocar seus quadros, tudo era feito improvisadamente [...] a repressão avançava $[\ldots .$.$] fui para Maceió [. .$.$] Estava sem meu companheiro que tinha sido preso$ [...] Fui para o sul, sem dinheiro pro ônibus. Parti de bermuda na boleia de um caminhão (ROCHA, 1978, p.177-181).

Fui presa em setembro (1968) na casa de amigos [...] Nos levaram de passagem pelo DOPS (Departamento de Ordem Política e Social) onde houve os primeiros bofetões e depois para a Ilha das Flores, onde funcionava o centro de torturas do Cenimar (Centro de Informações da Marinha). Fui para uma casinha [...] lá dentro uns 8 caras gritando: diz logo, abre o bico e bofetadas [...] Numa outra sala estava o telefone de choque elétrico e depois que me arrancaram a roupa, jogaram água para acordar do choque e sentir mais dor [...] Na ilha ficamos 6 meses [...] começaram greves de fome, protestos e nos transferiram para o presídio feminino em Bangu, onde passei 7 meses [...] Passei 01 ano e 3 meses presa e isso coincidiu com o inicio das ações armadas [...] Novembro de 1970 época das eleições a polícia prende 5000 pessoas só no Rio, alegando que era campanha preventiva contra agitações de esquerda. E lá fomos nós novamente (LISBOA, 1978, p.239-247).

A Operação Bandeirantes veio na nossa casa, na época no Brooklin [...] interrogou minha mãe, meu pai, e tivemos que sair mesmo [...] fiquei 6 meses clandestina [...] Morando na casa de pessoas que nos alojaram e a decisão foi sair [...] as pessoas que falaram depois de nós já falaram sob tortura violenta [...] foram presos e torturados juntos com filhos pequenos [...] era um período bem pesado 70, a época de Ibiúna era o começo da repressão [...] depois do AI 5 a repressão foi violenta [...] se eu ficasse teria sido presa, torturada [...] não tinha condições de ficar $[. .$.$] eu saí [. .$.$] poderia ter ficado clandestina mais tempo, mas seria$ difícil [...] já tava atrapalhando as pessoas que me ocultavam (HIRATA, 2011). 
Nessas circunstâncias, o exílio com a saída do país passou a ser visto por essas mulheres como única possibilidade para manter sua própria vida e evitar o comprometimento de seus vínculos pessoais e profissionais..

\section{ESTRATÉGIAS PARA SAIR}

Insegurança, perseguição, prisões, violência, tortura, desaparecimentos, mortes, o quadro institucional do regime autoritário que impunha o lema "Brasil: ame-o ou deixe-o" e as estratégias construídas por essas mulheres para sair do país caracterizam uma diáspora em escala local, regional, nacional e internacional.

Quando desenhamos tal mapa notamos estruturações vinculadas a comunidades representativas, que nos casos estudados se situam na prática política de esquerda, dispondo de redes de comunicação, acolhimento, transporte, documentação, etc.

As estratégias de exílio produzem diásporas com filiações a comunidades definidas: políticas, religiosas, étnicas (BRUNEAU, 2009). A princípio, consideraram a possibilidade de permanência em solo nacional: "[...] todos que tivemos problemas naquela época vivemos a clandestinidade. A gente ficou escondido na casa de alguém [...] continuava em São Paulo, as vezes bem perto de onde morava [...] a gente ficava num lugar, num quarto e não podia sair (HIRATA, 2011)."

Depois, a espera de retornar no curto prazo.

[...] saí sem a sensação de estar deixando as crianças. Pensei que as deixaria por 8 dias, certa que depois estariam comigo [...] como o clima psicológico era muito tenso, era um alívio saber que elas estavam em segurança [...]. Nunca me ocorreu que levaria anos sem vê-las (CARVALHO, 1987, p.61).

As fugas.

[...] Cheguei em São Paulo, aquele mundão [...] resolvi sair do pais (ROCHA, 1978, p.181). Saí do país de ônibus com documento de identidade falso [...] A unidade popular do Allende estava dando documentos com os quais a gente podia viajar [...] eu não tinha documento nenhum e tava sendo procurada [...] ai pude ir para França (HIRATA, 2011).

E o asilo político - importante instrumento de diplomacia internacional muito utilizado recentemente na América Latina: "Depois da nova soltura [...] nos escondemos [...] não saíamos na rua, não tínhamos contato com a família [...] tínhamos medo. Resolvemos procurar asilo em embaixadas (LISBOA, 1978, p.147)." 
Foragidas em circunstâncias em que a saída era a saída do país. Naquelas configurações, os depoimentos ajudam a construir e compreender as estratégias mobilizadas pelas quatro mulheres apontando acolhimentos em espaços ocupados por pontos com escalas variadas.

\section{ROTAS PERSEGUIDAS}

O exílio traçou circulações com rotas internas e externas. As fronteiras se romperam com a saída do país, via América do Sul, com conexão no Chile, cujo cenário político era de efervescência entre o governo Allende e o golpe de Pinochet. Diante do objetivo de perseguir rotas de fuga, elas conseguem certa guarida e, de lá passam a circular por vários países das Américas e Europa.

As memórias das mulheres explicitam as múltiplas partidas e chegadas características de situações de circulação. O mapeamento das rotas possíveis a cada uma indica que o exílio começou no Brasil.

Existiram as que contaram com intensa circulação interna.

[...] do Recife para Fortaleza [...] No Rio Grande do Norte, continuei o esforço vão de fazer algo, era impossível. Ao mesmo tempo o cerco policial apertava. Um companheiro cai hoje, outro amanhã, e eu escapulindo, sem saber como [...] a repressão avançava, fui para Maceió [...] Terminaram me levando até São Paulo [...] resolvi sair do país [...] Mas quando veio o golpe no Chile [...] Entrei na embaixada da Venezuela, fiquei 03 meses [...] Não sabíamos para onde ir [...] fomos aceitos pela Dinamarca (ROCHA, 1987, p.175-183).

Outras fracassaram no projeto de retornar em breve.

Não existe liberdade individual. Não existe garantia de defesa. Não existe nada [...] Saí, fui para o Chile, como a maioria das pessoas, foi enfim um clima de euforia, que era o Chile naquele período [...] Passada essa primeira fase, fui obrigada a viajar durante meses ininterruptos e me fixei em Paris (CARVALHO, 1987, p.53-65).

Ao mesmo tempo em que visaram permanência no Chile, foram impelidas à circulação por países latino-americanos e depois europeus.

Decidimos pelo Chile [...] Entramos no prédio [da embaixada] e ficamos 02 meses esperando o salvo-conduto [...] O jato levantou vôo e a gente se sentiu salva pela primeira vez. No aeroporto [de Santiago] havia muita gente e também a polícia [...] O golpe veio, acordamos com bombardeios e logo ouvimos o discurso de Pinochet [...] os tiroteios [...] Era a estupidez no poder [...] havia mortos e prisioneiros [...] o corpo de Allende metralhado na Praça de La Moneda. Os franco-atiradores agiam todo o dia [...] soubemos que o México estava dando 
asilo [...] não havia espaço no chão para deitar e nem comida. No dia seguinte viajou a primeira turma de chilenos junto com a viúva de Allende, para o México. Ficamos 12 dias na embaixada [...] fizemos uma viajem tranqüila acompanhados do embaixador mexicano, da Áustria, da Suécia [...] para conseguir respeito dos carabineiros chilenos que haviam cometido arbitrariedades em outros vôos [...] pensávamos que teríamos asilo no México [...] quando soubemos que o governo só daria asilo para chilenos [...] Ai começou uma romaria pelas embaixadas [...] Paquistão, Índia, Luxemburgo, sempre negativas. Finalmente a Iugoslávia estampou um visto de turismo de 01 ano [...] passamos pela Bélgica [...] uns ficaram lá. Seguimos para a Alemanha, onde tínhamos contato com a Amnesty International (LISBOA, 1978, p.249-253).

\section{Houve um destino predefinido.}

Eu fui pro Uruguai para sair do país [...] sai pelo Rio Grande do Sul de ônibus; de Montevidéu para o Chile. No Chile, em Santiago fiquei 01 mês [...] peguei o avião e cheguei na França em janeiro de 1971 (HIRATA, 2011).

No entrecruzamento não linear das rotas, internas e externas, todas passaram pelo Chile, transformando-se à medida que a perspectiva de volta para o Brasil se distanciava junto com as ditaduras que se estendiam na América do Sul.

\section{Outro estado nACIONAL}

As dificuldades linguísticas, culturais, materiais, profissionais, ruptura de vínculos são vividas ao lado da necessidade de reconversão identitária e de adaptação às situações. Foram muitas as experiências impostas pelo exílio.

Do irrecuperável ao adoecimento.

O lado negativo do exílio é a falta de adaptação. Se você chega numa nova terra e não fala a língua e tem péssimas condições materiais, não consegue se integrar [...] Do ponto de vista profissional foi muito ruim porque não posso ser advogada [...] Tenho um trabalho avulso, mal pago e sem garantia [...] Num clima psicológico em que você perdeu tudo o que era importante, estava numa fossa [...] me sentia aniquilada [...] adoeci [...] No começo morei em quartos de empregada [...] não tinham água quente, privada e banheiro. Havia uma piazinha de água fria e com sete andares para subir a pé. Era uma luta conseguir ticket de restaurante universitário, não tinha dinheiro mesmo nem pra comer. (CARVALHO, 1987, p.55-64).

A continuidade na militância e o engajamento político aparecem para algumas como continuidade da vida.

Fora do Brasil eu queria trabalhar, ser útil, estar junto à massa [...] No Chile procurei seguir meu curso de medicina e continuar a discussão com grupos polí- 
ticos [...] O Chile era um laboratório de marxismo [...] Foi brusco sair de um ambiente de repressão e isolamento e entrar num momento de amplitude política e ideológica [...] Me liguei ao Partido Socialista que se aproximava da massa [...] Começa a se agudizar a luta de classes e a direita lança ofensiva em 1972. Eu, como estudante de medicina tive participação direta [...] Trabalhava no Hospital Central, 24 horas de trabalho e de luta de classes. Foi um tempo muito triste, gente que não podia ser atendida e morria em nossas mãos [...] Quando veio o golpe, tudo ficou muito frágil [...] entrei na embaixada da Venezuela e fiquei 03 meses. (ROCHA, 1978, p.181-183).

Para outras provisoriedades, estranhamentos e dificuldades numa adaptação que era a única forma de sobrevivência.

Na Alemanha fomos para o único endereço de brasileiros que tínhamos [...] Esse pessoal foi solidário [...] A Amnesty reuniu os refugiados, deu as primeiras orientações, nos distribuiu em casas [...] Eu e meu companheiro ficamos 03 dias numa casa, uma experiência bem desagradável, parecia que os donos tinham medo de falar com a gente [...] eu estava meio mal de saúde. Estava grávida, com queda de pressão e fome crônica [...] a comida do restaurante estudantil onde comíamos 2 vezes por dia era pouca. Como sentíamos constrangidos nessa casa, só íamos lá dormir e passávamos o dia andando com ou sem neve. Depois nos levaram para outra. Nos alojaram num quarto confortável e foram gentis [...] temíamos estar incomodando e seguimos andando o dia inteiro e comendo no restaurante da escola. O dinheiro era curtíssimo e com a gravidez minha fome aumentava [...] uma instituição protestante nos ofereceu bolsas por 6 meses [...] estava grávida de 5 meses [...] mudamos para a cidade onde íamos estudar alemão [...] não aguentava mais [...] esperamos nossa filha nascer. Depois para Berlim onde cursamos a universidade (LISBOA, 1978, p.252- 253).

\section{brasileiros.}

Outra se vinculou à profissão e à rede relacional de exilados políticos

Faz 40 anos que estou na França [...] lá fiz mestrado, doutorado [...] em 1980 entrei no CNRS (Centre Nacional de Recherche Scientifique) [...] passei como pesquisadora 31 anos para me aposentar esse ano com 65 anos [...] trabalhei no CNRS como socióloga [...] a única universidade que me abriu as portas foi a de Vincennes, Paris $8[\ldots]$ não tinha outra que me recebesse sem documento nenhum a não ser o diploma [...] praticamente fiz toda minha atividade profissional lá $[\ldots]$ tive bolsa nos primeiros anos, e depois consegui um trabalho no aeroporto Charles de Gaulle [...] procuravam vendedora pra loja de queijo, vinho, caviar [...] que falasse japonês, português e inglês [...] fui contratada [...] trabalhei lá de 1973 a 1977 [...] de sábado, domingo, feriado e estudava vinte horas, era tempo parcial [...] tem o choque cultural [...] você vai num lugar que não tem nada que ver com sua cultura anterior [...] são pessoas muito diferentes [...] uma vez eu fui pegar uma fruta e bateram na minha mão [...] não estava acostumada com esse tratamento [...] na França acabei recriando uma sociabilidade brasileira porque muitos brasileiros exilados estavam lá: Prado Júnior, Mariinha, Samuel Pereira [...] depois de 1973, quando houve o golpe no Chile [...] a França acolheu muitos brasileiros [...] muita gente [...] conseguiu emprego (HIRATA, 2011). 
A construção identitária diaspórica é combinada e composta, vem marcada pela ligação com o país de origem e pelos elos tecidos nos diferentes espaços e tempos.

A diáspora supõe ancoragem no território de instalação e certa ruptura com o de origem, o que é compensado pela memória. Nessa realidade a identidade se esforça por ser recriada, reconvertida para melhor se reproduzir e se adaptar.

\section{EXÍlIO, VISÃO DE MUNDO E DE BRASIL}

A diáspora se opõe à dinâmica de constituição do Estado-nação pensado como território definido, delimitado e centralizado. Ela, contrariamente, é uma organização descentralizada, policêntrica e com limites e fluxos cartográficos mal definidos.

O exílio produz diáspora à medida que joga grupos nacionais em situações de mobilidade, em territórios circulantes, em várias escalas.

A experiência do exílio impactou a relação que essas mulheres tiveram com o país de origem e com os de acolhida.

\footnotetext{
No exílio nunca parei de preocupar com o Brasil [...] é uma forma de militância ativa, diária, obrigação. No Brasil não pertencia a nenhuma organização, não tinha esse tipo de diálogo, estudo [...] minha militância foi profissional [...] no exílio comecei a estudar e interessar pelo milagre econômico brasileiro [...] Continuo profundamente ligada ao Brasil. A gente morre de saudade [...] lá tenho as filhas [...] a terra da gente (CARVALHO, 1987, p.63-65).
}

Às vezes, o exílio é movimento para trás. É um jeito de viver como se tudo fosse temporário: "O exilio é um recuo, mas é preciso viver a realidade onde se esta [...] decidi estudar, aprender a língua dinamarquesa e me instrumentalizar com a técnica que essa gente tem, para depois poder trabalhar e voltar para a América Latina" (ROCHA, 1978, p.183).

Outras vezes, o deslocamento e o estranhamento produzem resistências à aculturação, dificultam filiações e lealdades.

[...] a universidade tem uma estrutura livre [...] A vida de cada um está programada desde o começo, pouca coisa pode ocorrer que mude. Isso traz certa tristeza e seriedade precoce nos jovens. O espírito competitivo é extremamente desenvolvido [...] de qualquer forma é a vida da gente passando [...] A Alemanha é um país estranho [...] realidade muito diferente, sociedade capitalista avançada. É desgraça entendê-la [...] conhecer o povo alemão exige adaptação cultural [...] eles viveram a fome, a guerra, a aceleração industrial [...] a desagregação de todos os vínculos emocionais [...] Ninguém fala do passado, Hitler é um nome banido, o alemão tem medo de ser alemão, tem vergonha de sua história recente. (LISBOA, 1978, p.253). 
Said (2003) sugere que o exilado desenvolve uma consciência contrapontista, pois os hábitos de vida, a expressão e as atividades no novo ambiente ocorrem tendo como pano de fundo as memórias das situações de outro ambiente. Assim, ambos os ambientes são vividos e sentidos juntos, como reais e como contraponto.

[...] na França entrei imediatamente nas atividades políticas de frente, de solidariedade com o que estava se passando no Brasil [...] tinha uma série de atividades que a gente fazia para angariar fundos, vários boletins [...] tive atividade intensa até $79[\ldots]$ em relação a anistia, a gente chegou a fazer greve de fome numa igreja $[\ldots]$ nunca perdi contato com o Brasil [...] consegui manter um vínculo profissional e afetivo [...] é muito doloroso saber que amigos, militantes foram torturados, morreram [...] é uma coisa viva para mim [...] eu sonhava sendo perseguida pela polícia, tinha de correr e não conseguia [...] eu lembro que tive sonhos de angústia, de fuga. (HIRATA, 2011).

As dificuldades alinharam-se ao desejo de manter contatos com a situação política, cultural e econômica de origem e a afirmação da identidade brasileira.

O exílio não precisa ser um tempo morto para mim [...] também não é uma separação imposta que nos arranca de nossos costumes, língua, cultura [...] Talvez ao contrário, viver fora de nossa terra nos faz mais conscientes dessas coisas. Me sinto mais brasileira do que nunca e com mais direitos às palmeiras e sabiás do que muito outros que estão lá (LISBOA, 1978, p.254).

Em seus percursos, essas mulheres permaneceram militando em causas políticas vinculadas à esfera pública, imersas na diáspora política brasileira. As memórias narradas apontam para a compreensão do exílio como um ato político coletivo e individual, com cenários factuais e sensíveis.

\section{A CONDIÇÃO DA MULHER}

A "chave da cadeia" para essas mulheres no final de 1960, no Brasil, segundo depoimentos, estava na militância estudantil, na participação em organização política ou atuando profissionalmente na defesa dos direitos de cidadãos presos ou ameaçados pelo regime militar.

Houve diversidade nos recursos detidos, nos percursos de reconversão e nas estratégias. Elas viviam em grandes centros urbanos, eram escolarizadas e tinham contato com a vida universitária, com o curso superior concluído ou em andamento. Os processos que as levaram ao exílio arrolaram situações de delação, perseguição, prisão e tortura.

Enquanto alvos políticos do Estado, familiares, filhos e pessoas próximas, foram envolvidos. A incomunicabilidade e o alheamento em relação à vida cotidiana estavam colocados. A perseguição iniciava-se com interroga- 
tórios policiais e ameaças, avançava para processos criminais e prisões, e culminava com a clandestinidade, a fuga e o exílio.

Segundo as narrativas, o exilio gerava complicações para as mulheres. Além do afastamento em relação à família, aos filhos e amigos, a discriminação e a desmoralização em função do sexo/gênero ${ }^{11}$, faziam-se presentes de forma contundente em situações vividas tanto de enfrentamento nos ambientes de estudo, militância e trabalho, quanto de fuga e de confronto com as forças repressivas.

Uma delas ao reportar a situação vivida no Brasil, enfatiza que na luta política a repartição das tarefas entre os sexos não traduzem complementaridade, mas uma relação de poder dos homens sobre as mulheres (KERGOAT, 2009).

A primeira meta foi tomar o diretório (dos estudantes de medicina) que estava com a direita. Foi aí que senti a discriminação contra a mulher: os fascistas usavam minha condição de mulher para tentar derrubar-nos. Quando eu passava o pessoal cercava e fazia fiu-fiu tentando me desmoralizar. Como não podiam me combater politicamente nas assembléias, partiam para o vexame moral (ROCHA, 1978, p.178).

As relações sociais entre os sexos constituíam um complicador até mesmo entre aqueles que direta ou indiretamente auxiliavam em situações de fuga, elas traduzem hierarquização e dominação do homem sobre a mulher.

Parti de bermuda na boleia de caminhão. O motorista, eu no meio e um ajudante [... No terceiro dia os caras quiseram me pegar na marra. Eu, sem saber o que fazer, comecei a chorar, saí do caminhão e um deles se arrependeu e terminaram me levando até São Paulo. (ROCHA, 1978, p.181).

Existe um sistema social sexuado que monopoliza para os homens o acesso a lugares, papéis, funções. Isso aparece também na cadeia entre os que lutam a favor da justiça e da igualdade social e que acabam por receber um tratamento diferente e desigual em virtude da condição de ser mulher.

\footnotetext{
Durante uma semana, não aconteceu nada, a não ser visitas diárias dos oficiais (era um regimento). Esses caras vinham nos visitar e falar dos outros prisioneiros [...] falavam cinicamente sobre a situação da tortura e que eles achavam horrível as nossas caras, inchadas e roxas, e diziam "pobres moças". (LISBOA, 1978, p.242).
}

As desigualdades de sexo existentes nas práticas sociais perduravam durante o exílio, pois a divisão sexual do trabalho destinava aos homens a esfera produtiva e às mulheres a reprodutiva. Nessa repartição de tarefas as funções de forte valor social agregado no campo organizacional, político, 
religioso, militar etc. são ocupadas pelos homens e as funções subordinadas destinadas as mulheres. Dentre essas se encontra o trabalho invisível, feito para os outros e não remunerado da maternidade. Ter filhos é um sério problema para as mulheres [...] muitas vezes implica em ter
que deixar o trabalho. A rede de creches estatais [na Alemanha] não é suficiente
e a ajuda para as famílias é pequena. Tenho tido uma vida extremamente difícil
depois que nasceu minha filha, porém luto para não renunciar às minhas ativida-
des universitárias, nem as maternais. (LISBOA, 1978, p.254).

As relações sociais de sexo não são provenientes de causalidades biológicas, são construções sociais, têm base material e se expressam na divisão sexual do trabalho. Essa ordem prática toma corpo nas instituições, legislações e representações que regulam as posições de força entre os sexos num momento dado, elas induzem o funcionamento do social. Os depoimentos apontam que o código civil é atravessado pelas relações de poder entre os sexos (KERGOAT, 2009).

\footnotetext{
Era arrimo de família [...] desquitei a caçula tinha 3 meses e a mais velha 2 anos [...] me tornei pai e mãe e desenvolvi uma ligação afetiva muito grande com elas. A mais velha tinha 7 anos quando saí [...] eu vivia em função delas e da profissão [...] Do dia para a noite me senti privada das duas coisas que mais amava. Tudo caiu por terra. A gente consegue superar intelectualmente porque encontra outro tipo de atividade [...] mas afetivamente não. Do ponto de vista afetivo sou uma mulher extremamente frustrada [...] A sentença que me tirou a guarda das filhas se baseou unicamente em motivos políticos. O juiz no Brasil me declarou má cidadã, sem condições cívicas de educar duas pequenas brasileiras [...] os meus delitos são: defender presos políticos e denunciar torturas (CARVALHO, 1978, p.57-65).
}

As memórias apontaram que no exilio, mesmo entre os grupos feministas, nos posicionamentos perdurava a divisão sociossexual do trabalho que delega às mulheres as tarefas que valem menos (MATHIEU, 2009).

[...] as diferenças estão aí nas restrições diversas que se levantam a uma melhor colocação das mulheres nos empregos, no trabalho doméstico que ainda é sua obrigação além de trabalhar fora [...] na mentalidade dominante tem ainda uma superioridade masculina [...] É muito difícil para uma mulher decidir não ter filhos, a fim de ter melhores condições de competição com os homens porém é uma atitude capitulacionista. Boa parte do movimento feminista europeu tem esta atitude, em minha opinião devíamos lutar para que a sociedade assumisse coletivamente a carga dos filhos. (LISBOA, 1978, p.254).

\section{DESFECHOS}

O exílio transformou a visão que cada mulher tinha de si mesma e as formas como passaram a ser percebidas pelos outros, seja pelas pessoas 
que integravam seus grupos de convivência, seja pelas que vieram a integrar suas relações na condição de exiladas. E se associou à percepção de desprestígio, desconsideração, desclassificação econômica, social e simbólica. Podemos dizer que o exílio provocou nelas reconversões identitárias atravessadas por dimensões simultâneas e consciências contrapontistas.

O exílio impactou ainda as dinâmicas sociais envolvidas nas relações de sexo/gênero. As narrativas apontam que nem a militância politica de esquerda nem o exilio conseguiram alterar a repartição tradicional do trabalho que reserva aos homens a esfera produtiva e valorizada e às mulheres a reprodutiva e invisível dispondo homens e mulheres em posições diferentes e desiguais na hierarquia e no status quo.

Depois desses anos, desde o golpe de 1964, a ditadura instaurada e o exílio percorrido, nota-se, por um lado, o comprometimento político e ideológico com a libertação da América Latina que viveu sob regimes ditatoriais e, por outro, manifestações como forma de impedir a repetição de governos ditatoriais, de recusar situações sociais de opressão, exclusão, discriminação e violação dos direitos.

Nas memórias dessas mulheres pulsam o Brasil e a América Latina como dimensões da relação humanidade-realidade-conhecimento que descrevem processos e fortalecem a sociedade civil e os princípios de liberdade e vida.

\section{REFERÊNCIAS BIBLIOGRÁFICAS}

BAUER, Carlos. A natureza autoritária do Estado no Brasil contemporâneo. Elementos de história e questionamentos políticos. São Paulo: José Luís e Rosa Sundermann, 2012.

BAUER, Martin \& GASKELL, George. Pesquisa qualitativa com texto, imagem e som: um manual prático. Rio de Janeiro: Vozes, 2010.

BENJAMIN, Walter. O narrador: considerações sobre a vida de Nikolai Leskov. In Magia e técnica, arte e politica, S.P.: Brasiliense, 4a . edição, 1997, p. 197-221.

BRUNEAU, Michel. Pour une approche de la territorialité internationale: lês notions de diáspora et de communauté transnationale. In: ARAB, C. [et al.] (Org.) Les circulations transnationales. Lire les turbulences migratoires contemporaines. Paris: Armand Colin, 2009.

CARVAlHO, Anina de. Entrevista. In: CAVAlCANTI, Pedro U. RAMOS, Jovelino (Orgs.). Memórias do exílio. Brasil 1964/19?? De muitos caminhos. São Paulo: Livramento Ltda, 1978. CORTES, Genevière; FARET, Laurent. La circulation migratoire dans l'ordre dês mobilités. In: ARAB, C. [et al.] (Org.). Les circulations transnationales. Lire les turbulences migratoires contemporaines. Paris: Armand Colin, 2009.

COSTA, Albertina de O; MORAES, Maria T. P.; MARZOLA, Norma \& LIMA, Valentina da R. (Orgs.). Memórias das mulheres do exílio. Rio de Janeiro: Paz e Terra, 1980. 
DREIFUSS, René A. 1964, a conquista do Estado: ação política, poder e golpe de classe. Petrópolis: Vozes, 2008.

DUBAR, Claude. A socialização: construção das identidades sociais e profissionais. São Paulo: Martins Fontes, 2005.

DUBET, François. Sociologia da Experiência. Lisboa: Instituto Piaget, 1996.

DUSSET, Annie [et al.]. Le genre est-il soluble dans les associations feministes? Cahier du Genré, $\mathrm{n}^{\circ}$. 55, 2013.

FERNANDES, Florestan. A revolução burguesa no Brasil: ensaio de interpretação sociológica. Rio de Janeiro: Editora Jorge Zahar, 1975.

As Trocinhas do Bom Retiro: Contribuições ao estudo folclórico e sociológico da cultura dos grupos infantis. Pro-Posições: Campinas, v. 15, n. 1, 2004.

GORENDER, Jacob. Combates nas trevas. A esquerda brasileira: Das ilusões perdidas à luta armada. São Paulo: Ática, 1987.

HALL, Stuart. Da diáspora: Identidades e mediações culturais. Belo Horizonte: UFMG, 2006.

HELLER, Agnes. Sociologia de la vida cotidiana. Barcelona: Península, 1977.

HIRATA, Helena. Entrevista concedida às autoras. São Paulo, 2011.

KERGOAT, Daniele. Divisão sexual do trabalho e relações sociais de sexo. In: HIRATA, Helena [et al.] (Org). Dicionário crítico do feminismo. São Paulo: UNESP, 2009.

LARROSA, Jorge. Notas sobre a experiência e o saber da experiência. Revista Brasileira de Educação: Rio de Janeiro, $\mathrm{n}^{\circ}$ 19, 2002.

LISBOA, Marijane V. (1978). Entrevista. Entrevista. In: CAVALCANTI, Pedro U. \& RAMOS, Jovelino (Orgs.). Memórias do exílio. Brasil 1964/19?? De muitos caminhos. São Paulo: Livramento Ltda, 1978.

MATHIEU, Nicole-Claude. Sexo e gênero. In: HIRATA, Helena [et. al.] (Org.). Dicionário crítico do feminismo. São Paulo: UNESP, 2009.

QUEIROZ, Maria Isaura P. Relatos orais: do indizivel ao dizivel. In Textos CERU, São Paulo: Humanitas, Série 2, no. 10, 2008, p. 35-78.

REZENDE, Maria J. de. A ditadura militar no Brasil: repressão e pretensão de legitimidade 1964-1984. Londrina: Editora Universidade Estadual de Londrina, 2001.

ROCHA, Juliana da. Entrevista. In: CAVALCANTI, Pedro U. \& RAMOS, Jovelino (Orgs.). Memórias do exílio. Brasil 1964/19?? De muitos caminhos. São Paulo: Livramento Ltda, 1978. ROLLEMBERG, Denise. Exílio entre raizes e radares. Rio de Janeiro: Record, 1999.

SAID, Edward. Reflexões sobre o exílio e outros ensaios. São Paulo: Cia das Letras, 2003.

SAINT MARTIN, Monique de. Reconversões e reestruturações das elites: o caso da autocracia em França. Análise Social, Vol. 30, 1995.

TOLEDO, Caio Navarro de. O governo Goulart e o golpe de 1964. São Paulo: Brasiliense, 1982.

YANKELEVICH, Pablo \& JENSEN, Silvina (Orgs.). Exilios: destinos y experiências bajo la dictadura militar. Buenos Aires: Libros Del Zorzal, 2007. 